\title{
EMISSION OF POLYCHLORINATED DIBENZO-P-DIOXINS AND POLYCHLORINATED DIBENZOFURANS FROM UNDERFIRING SYSTEM OF COKE OVEN BATTERY
}

\author{
Rafał Bigda' ${ }^{1}$, Wojciech Urbańczyk ${ }^{2}$, Andrzej Mianowski ${ }^{1}$, Aleksander Sobolewski ${ }^{1}$ \\ 1 Institute of Chemical Processing of Coal, Zamkowa 1, 41-800 Zabrze, Poland \\ 2 Silesian University of Technology, Faculty of Chemistry, Department of Inorganic Chemistry, Analytical \\ Chemistry and Electrochemistry, Krzywoustego 6, Gliwice, Poland
}

Corresponding author's e-mail: rbigda@ichpw.pl

Received: 2017.09.04

Accepted: 2017.10.01 Published: 2017.11.01

\begin{abstract}
A coke oven battery is not considered as a significant source of polychlorinated dibenzo-p-dioxins (PCDDs) and polychlorinated dibenzofurans (PCDFs) emissions; however, due to small amounts of chlorine in coal dioxins, dibenzofurans may be formed. The paper presents the attempts to determine the level of emission of PCDDs/PCDFs from the $\mathrm{COB}$ underfiring system and to confront the obtained results with the calculations based on the mass balance of chlorine in the coking process and reactions of both chlorophenols formation and PCDDs and PCDFs formation from mono- and polychlorophenols. There were PCDDs/PCDFs concentrations measured in flue gases from the underfiring system of two COBs at a Polish coking plant. The measurements included both an old and a new battery. The obtained concentrations of PCDDs/ PCDFs were lower than reported in the literature $\left(0.5-1.7 \mathrm{ng} \mathrm{I-TEQ} / \mathrm{Mg}_{\text {coke }}\right)$, while the results for old $\mathrm{COB}$ were on average 3 times higher than for the new one. It was found that $\mathrm{PCDDs} / \mathrm{PCDF}$ emission from $\mathrm{COB}$ underfiring system is insignificant and that PCDDs/PCDFs formation during coal coking should consider the mechanisms of their formation from mono- and polychlorophenols, as well as the influence of process parameters on the synthesis.
\end{abstract}

Keywords: coke oven battery, PCDDs, PCDFs, dioxins, emission measurement, coke plant

\section{INTRODUCTION}

Since the introduction of Regulation No. $166 / 2006$ by the European Union on pollutant release and transfer, coking plants are required to keep a record of the data that illustrate the input and transport of pollutants in the environment. The introduction of this directive imposed an obligation to create National Pollutant Release and Transport Registers on the Member States territories, which will become part of the European Pollutant Release and Transport Register (E-PRTR). According to this act, the limits of individual pollutants concentrations formed during the cok- ing process have been fixed. These include: $\mathrm{CH}_{4}$, $\mathrm{CO}, \mathrm{CO}_{2}, \mathrm{NH}_{4}, \mathrm{NMVOC}$ (non-methane volatile organic compounds), $\mathrm{NO}_{x}, \mathrm{SO}_{x}$, heavy metals and their compounds $(\mathrm{As}, \mathrm{Cd}, \mathrm{Cr}, \mathrm{Cu}, \mathrm{Hg}, \mathrm{Ni}$, $\mathrm{Pb}, \mathrm{Zn}$ ), PCDDs (polychlorinated dibenzo-p-dioxins) and PCDFs (polychlorinated dibenzofurans), anthracene, benzene, naphthalene, PAHs (polycyclic aromatic hydrocarbons), HCN and $\mathrm{PM}_{10}$ (particulate matter, fraction below $10 \mu \mathrm{m}$ ) [Regulation EC 2006].

Coking plants are usually divided into four main production units, which comprise the coal yard, coke ovens, by-product plant and coke sorting and handling. The main and key unit of coke 
production is a battery of coke ovens [Sobolewski 2005]. The emission of compounds as defined by EU regulation can occur in each of these units.

Transport of air pollutants into the environment from pyrolysis of coal may occur by [Sobolewski 2010]:

a) stack emission (underfiring system),

b) fugitive emission from coke oven battery (COB) point sources (oven doors, charging lids, coal charging, coke pushing),

c) emission from coke quenching process.

Table 1 presents the sources of emission at coking plant depending on the type of pollution [Sobolewski 2010]. Hence, one potential source of PCDDs and PCDFs is COB, which consists in an underfiring system, besides coal tower, battery equipment and quenching tower [Sobolewski 2005]. Typical ranges of PCDDs/PCDFs emissions factors at coking plants are generally very low and vary depending on the source: the lowest ones are for charging lids $\left(<4 \mathrm{ng} \mathrm{I}-\mathrm{TEQ} / \mathrm{Mg}_{\text {coke }}\right.$, while the highest ones are observed at underfiring system, quenching tower and oven doors $(<20,<$ 20 and $<35 \mathrm{ng}$ I-TEQ $/ \mathrm{Mg}_{\text {coke }}$, respectively) [Hein 2009]. No influence of the type of underfiring gas (coke oven gas/mixed gas) could be examined with regard to the PCDDs/PCDFs emissions from underfiring system. It is to assume that the level of PCDDs/PCDFs emissions at the quenching tower is influenced by the completeness of carbonisa-

Table 1 Air pollutants at coking plant depending on the source [Sobolewski 2005]

\begin{tabular}{|c|c|c|c|c|}
\hline & Coal yard & $\begin{array}{l}\text { Coke } \\
\text { ovens }\end{array}$ & $\begin{array}{c}\text { By- } \\
\text { product } \\
\text { plant }\end{array}$ & $\begin{array}{l}\text { Coke sorting } \\
\text { and handling }\end{array}$ \\
\hline TSP & + & + & + & + \\
\hline $\mathrm{PM}_{10}$ & + & + & + & + \\
\hline $\mathrm{NO}_{\mathrm{x}}$ & + & + & + & - \\
\hline $\mathrm{SO}_{\mathrm{x}}$ & + & + & + & - \\
\hline PAH & + & + & + & - \\
\hline $\mathrm{CH}_{4}$ & + & + & + & - \\
\hline $\mathrm{CO}$ & + & + & + & - \\
\hline $\mathrm{CO}_{2}$ & + & + & + & - \\
\hline $\begin{array}{l}\text { heavy } \\
\text { metals }\end{array}$ & - & + & + & + \\
\hline benzene & - & + & - & - \\
\hline $\mathrm{H}_{2} \mathrm{~S}$ & - & + & + & - \\
\hline $\begin{array}{l}\text { PCDD + } \\
\text { PCDF }\end{array}$ & - & + & - & - \\
\hline NMVOC & - & + & - & - \\
\hline $\mathrm{NH}_{3}$ & - & + & - & - \\
\hline $\mathrm{HCN}$ & - & + & - & - \\
\hline
\end{tabular}

tion of coal charge. It is necessary to mention that the provided values have not been updated since at least 10 years and come from a single German installation.

In accordance with the EU Regulation No. $166 / 2006$, in the case of exceeding the concentration of a pollutant at coking plant, it is required to notify the institutions responsible for environmental protection established in the EU countries.

\section{AIM OF THE WORK}

The aim of this work is an attempt to determine the level of emission of PCDDs/PCDFs from the $\mathrm{COB}$ underfiring system and to confront the obtained results with the calculations based on the mass balance of chlorine in the coking process and reactions of both chlorophenols formation and PCDDs and PCDFs formation from mono- and polychlorophenols. In addition, the work is also of cognitional character, since there were no such measurements at Polish coking plants so far. These measurements should be considered as preliminary or identification ones, because their main objective was to verify if there is any PCDDs/PCDFs emission from COB - and if so, how big is it - rather than to evaluate their unambiguous level.

\section{CHARACTERSTICS OF PCDDS AND PCDFS}

In literature, polychlorinated dibenzodioxins (PCDDs) and polychlorinated dibenzofurans (PCDFs) are often referred to by means of a joint, imprecise name of dioxins and furans. These compounds are members of chlorinated aromatic compounds [Alcock \& Jones 1996, Brzuzy \& Hites 1996, Fiedler 1993]. Figure 1 presents the structure of dibenzodioxin and dibenzofuran detailing the position that can be occupied by a chlorine atom.

From Figure 1 it follows that dibenzodioxin and dibenzofuran molecules contain eight positions, where hydrogen atoms may be substituted with chlorine atoms. Accordingly, there are 75 congeners of PCDDs and 135 congeners of PCDFs. Table 2 lists all the congeners with a given number of chlorine atoms.

In general, the source of dioxin formation can be divided into anthropogenic and natural. Natural 

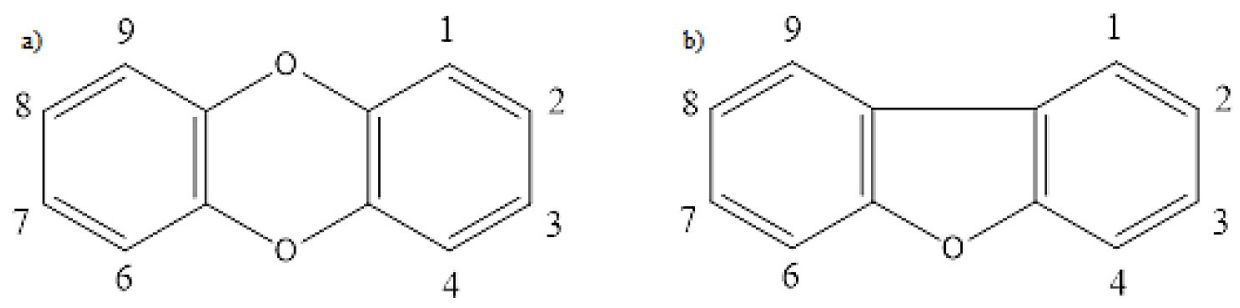

Fig. 1 Structure of a) dibenzodioxin, b) dibenzofuran with numeration of carbon atoms.

Table 2 Number of possible PCDDs and PCDFs congeners [Brzuzy \& Hites 1996].

\begin{tabular}{|c|c|c|}
\hline \multirow{2}{*}{$\begin{array}{c}\text { Number of halogens } \\
\text { number }\end{array}$} & \multicolumn{2}{|c|}{ Number of isomers } \\
\cline { 2 - 3 } & PCDDs & PCDFs \\
\hline 1 & 2 & 4 \\
\hline 2 & 10 & 16 \\
\hline 3 & 14 & 28 \\
\hline 4 & 22 & 38 \\
\hline 5 & 14 & 28 \\
\hline 6 & 10 & 16 \\
\hline 7 & 2 & 4 \\
\hline 8 & 1 & 1 \\
\hline Total & $\mathbf{7 5}$ & $\mathbf{1 3 5}$ \\
\hline
\end{tabular}

sources mainly include the formation processes of crude oil, natural gas, oil shale, as well as forest fires and the activity of microorganisms [Alcock \& Jones 1996, Brzuzy \& Hites 1996, Fiedler 1993]. The anthropogenic sources mainly include municipal waste incineration plants, steel plants, cement kilns (not burning hazardous waste), biomass combustion, incineration of medical waste, secondary copper smelting and cars consuming leaded and unleaded fuel [Alcock \& Jones 1996]. Dioxins may be also formed during chemical, thermal, photochemical and enzymatic reactions. It is understood that polychlorinated dibenzo-pdioxins and polychlorinated dibenzofurans are formed in each thermal process, if the combustion environment is organic matter and chlorine is present. The ways of formation and emission of dioxins in the combustion process are as follows [Brzuzy \& Hites 1996, Jones et al. 1994]:

- burned material contains dioxins, however, as a result of low temperature combustion they did not decompose,

- gas phase synthesis (temperatures above $500^{\circ} \mathrm{C}$ ) from organic precursors, such as mono- and polychlorinated phenols,

- catalytic synthesis on dust surface; the catalysts for this reaction are metal particles contained in the dust, including copper, iron, nickel and zinc; chloroorganic derivatives also constitute the precursors to the formation of dioxins,

- as a result of de novo synthesis (temperature $250-700{ }^{\circ} \mathrm{C}$ ), the precursors of which include organic radicals, carbon black and chlorine,

- as a result of the reaction with polycyclic aromatic hydrocarbons (PAHs); the reaction also proceeds on the surface of dust particles and is catalysed by metals in the dust (temperature $\left.250-400{ }^{\circ} \mathrm{C}\right)$.

Figures 2 and 3 show the possible mechanisms of PCDDs and PCDFs formation [Wielgosiński 2009, Ryu 2008]. PCDDs and PCDFs are colorless, solid bodies with wide range of melting points [Alcock \& Jones 1996, Brzuzy \& Hites 1996]. Generally, it can be assumed that the value of the melting point increases along with the number of chlorine atoms in the molecule of a xenobiotic. PCDDs and PCDFs are also characterized by low vapor pressures, high boiling points, high thermal stabilities and the lack of resistance to ultraviolet radiation. According to the principle similia similibus solventur dioxins exhibit the greatest solubility in o-dichlorobenzene (of the order of $1.4 \mathrm{~g} / 1$ ), and the lowest in water (only a few micrograms per liter). They are also characterized by high solubility in lipids, which is a cause of accumulation in human tissues [Wielgosiński 2009, Ryu 2008, Griffin 1986, Grochowalski \& Lasa 1989]. Thanks to these properties, they have been recognized as the compounds that are particularly dangerous to the human health. The 2,3,7,8-tetrachlorodibenzo-p-dioxin and 1,2,3,7,8-pentachlorodibenzo-p-dioxin have specific properties in this manner and the value of the toxicity equivalent factor (TEF) is 1 . The toxic effects of PCDDs PCDFs cause disorders of the immune system, which leads to reduction of reproductive capacity. Although they do not have direct carcinogenic effects, they have been recognized by the International Agency for Research on Cancer (IARC) in Lyon as a group A carcino- 

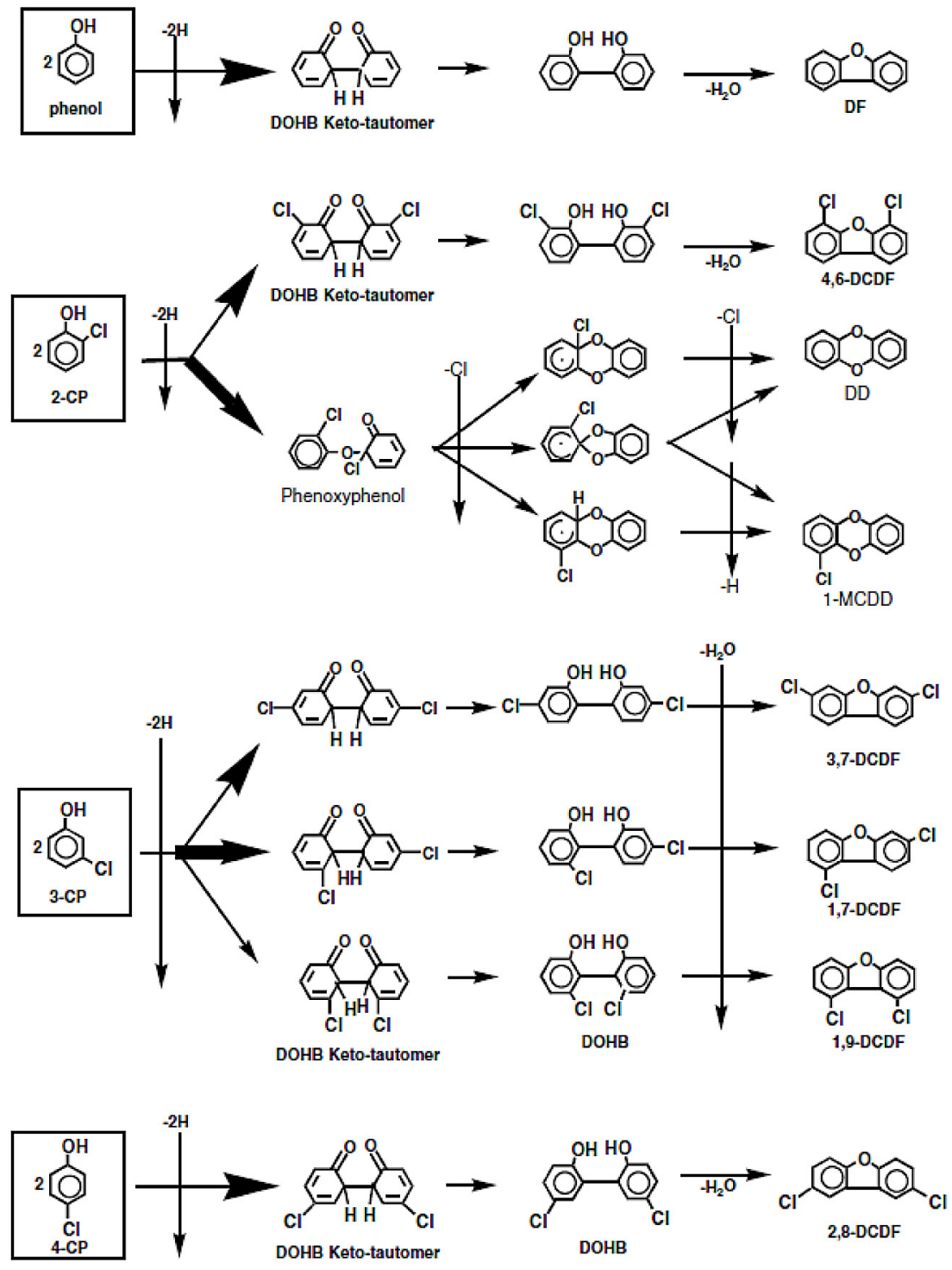

Fig. 2. Mechanisms of PCDDs and PCDFs formation [Ryu 2008]

gen. The carried out studies also confirmed the harmful effect of PCDDs and PCDFs on DNA. Teratogenic and allergic effects were also proven.

According to the information provided in the regulation approved by the BREF document [BREF 2013], the threshold level of PCDDs/ PCDFs for coke oven underfiring is $0.001 \mathrm{ng}$ I-TEQ/ $\mathrm{Nm}^{3}$ [Alcock \& Jones 1996, Brzuzy \& Hites 1996, Grochowalski \& Lasa 1989]. In the assessment of the toxicity of exhaust gases, the so called toxic equivalency (TEQ) is calculated, which is a standardised parameter. For this purpose, the toxic equivalency factor (TEF) is used. Numerical values of TEF are within the range of $0.001-1$ and determine the relative toxicity of each of PCDD and PCDF congeners in relation to the most toxic 2,3,7,8-tetrachlorodibenzop-dioxin $(2,3,7,8$-TCDD), for which TEQ $=1$.
Using the value of TEQ, one may determine the potential toxicity of exhaust gases in relation to PCDDs and PCDFs and compare it with limit values. TEQ is calculated from equation (1):

$$
T E Q=\sum_{i=1}^{i=17}\left(\mathrm{~m}_{\mathrm{i}} \times \mathrm{TEF}_{\mathrm{i}}\right)
$$

where: $m_{i}-$ mass of single congener,

$T E F_{i}$ - factor equivalent to toxicity for $i$ $\mathrm{PCDDs} / \mathrm{PCDFs}$ congener in relations to congener 2,3,7,8-TCDD.

The values of TEF factor for particular PCDDs and PCDFs congeners are different (Table 3) [Brzuzy \& Hites 1996, Wielgosiński 2008].

Polychlorinated dibenzo-p-dioxins and polychlorinated dibenzofurans may be discharged 
<smiles>C=Cc1cc(Cl)c(Oc2cc(Cl)cc(Cl)c2O)c(Cl)c1</smiles><smiles>[2H]c1c(Cl)cc(Cl)cc1Oc1c(Cl)cc(Cl)cc1Cl</smiles><smiles>Clc1cc(Cl)c(Oc2cc(Cl)cc(Cl)c2Oc2c(Cl)cc(Cl)cc2Cl)c(Cl)c1</smiles><smiles>Clc1cc(Cl)c2c(c1)Oc1cc(Cl)cc(Cl)c1O2</smiles><smiles>O=C(Oc1c(Cl)cc(Cl)cc1Cl)c1cc(Cl)cc(Cl)c1Cl</smiles>

Fig. 3. The mechanism of PCDDs formation by condensation - Smiles rearrangement of with compound of dioxaspiro type and creation of dibenzodioxin [Wielgosiński 2009]

Table 3. Values of TEF factor for particular PCDDs and PCDFs congeners [Brzuzy \& Hites 1996, Wielgosiński 2008]

\begin{tabular}{|c|c|c|c|}
\hline PCDDs congeners & TEF & PCDFs congeners & TEF \\
\hline $2,3,7,8-$-TCDD & 1 & $2,3,7,8-$ TCDF & 0.1 \\
\hline $1,2,3,7,8-\mathrm{P}_{5} \mathrm{CDD}$ & 1 & $2,3,4,7,8-\mathrm{P}_{5} \mathrm{CDF}$ & 0.5 \\
\hline $1,2,3,4,7,8-\mathrm{H}_{6} \mathrm{CDD}$ & 0.1 & $1,2,3,7,8-\mathrm{P}_{5} \mathrm{CDF}$ & 0.05 \\
\hline $1,2,3,6,7,8-\mathrm{H}_{6} \mathrm{CDD}$ & 0.1 & $1,2,3,4,7,8-\mathrm{H}_{6} \mathrm{CDF}$ & 0.1 \\
\hline $1,2,3,7,8,9-\mathrm{H}_{6} \mathrm{CDD}$ & 0.1 & $1,2,3,6,7,8-\mathrm{H}_{6} \mathrm{CDF}$ & 0.1 \\
\hline $1,2,3,4,6,7,8-\mathrm{H}_{7} \mathrm{CDD}$ & 0.01 & $1,2,3,7,8,9-\mathrm{H}_{6} \mathrm{CDF}$ & 0.1 \\
\hline $1,2,3,4,6,7,8,9-\mathrm{H}_{8} \mathrm{CDD}(\mathrm{OCDD})$ & 0.0001 & $2,3,4,6,7,8-\mathrm{H}_{6} \mathrm{CDF}$ & 0.1 \\
\hline & & $1,2,3,4,6,7,8-\mathrm{H}_{7} \mathrm{CDF}$ & 0.01 \\
\hline & & $1,2,3,4,7,8,9-\mathrm{H}_{7} \mathrm{CDF}$ & 0.01 \\
\hline & & $1,2,3,4,6,7,8,9-\mathrm{H}_{8} \mathrm{CDF}(\mathrm{OCDF})$ & 0.0001 \\
\hline
\end{tabular}


by stack emission (battery underfiring system [Sobolewski 2005]) during coal pyrolysis in $\mathrm{COB}$, while their presence in fugitive emission is usually ignored.

\section{MEASUREMENTS OF PCDDS/PCDFS CONCENTRATIONS FROM UNDERFIRING SYSTEM OF COB}

Experimental approach was based on the measurement of PCDDs/PCDFs concentration from waste gases in underfiring system of 2 selected COBs located in one of the Polish coking plants: an old one, 1 year before shutting down (COB-O) and a new one, 5 years after start-up (COB-N). There were three 8-hour consecutive sampling of exhaust gases directly from:

- the stack at a height of $43 \mathrm{~m}$, where there was located service platform with the access to sampling sockets (COB-N),

- the waste-gas flue, with sampling sockets located in the shed next to battery (COB-O).

The measurements were carried out according to the Polish standard [BS EN 1948-1:2006]. Zambelli sampling system was used on the sampling site (Fig. 4). Before the start of sampling and afterwards, the reference PCDDs and PCDFs were introduced, which were labelled with ${ }^{13} \mathrm{C}$. This action was intended to determine the size of the analyte loss.

Table 4 presents the sampling conditions, whereas the measured concentrations and calcu- lated emission factors of PCDDs and PCDFs are presented in Table 5.

\section{DISCUSSION}

The obtained results show trace quantities of PCDDs and PCDFs originating from underfiring system of $\mathrm{COB}$. The obtained values are significantly lower than those in the literature

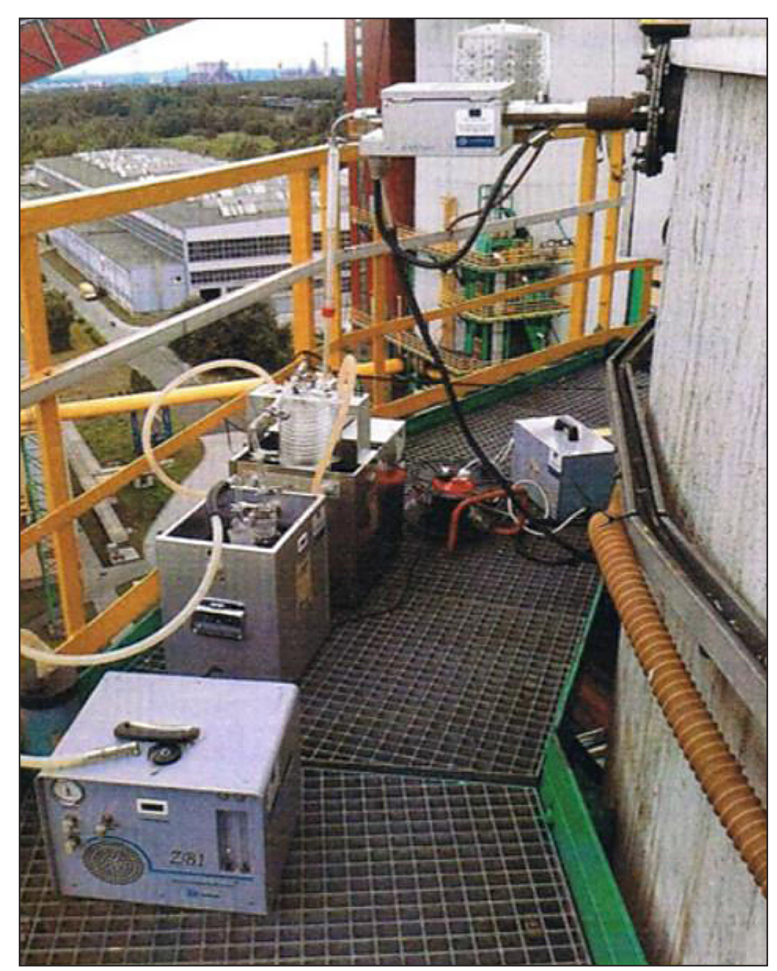

Fig. 4. $\mathrm{PCDD} / \mathrm{PCDF}$ sampling site on $\mathrm{COB}-\mathrm{N}$ stack (at the height of $43 \mathrm{~m}$ )

Table 4. PCDDs/PCDFs sampling conditions from 2 COB underfiring systems

\begin{tabular}{|l|c|c|c|}
\hline \multicolumn{1}{|c|}{ Parameter } & Unit & COB-O & COB-N \\
\hline Average waste-gas velocity & $\mathrm{m} / \mathrm{s}$ & 6.3 & 2.4 \\
\hline Average waste-gas temperature & ${ }^{\circ} \mathrm{C}$ & 222.4 & 230.5 \\
\hline Gas flue diameter & $\mathrm{m}$ & 3.3 & 4.5 \\
\hline $\mathrm{O}_{2}$ content in waste-gas & $\%$ & 12.6 & 8.7 \\
\hline Sampling location & - & waste-gas flue (to stack) & stack \\
\hline
\end{tabular}

Table 5. Measured PCDD/PCDF concentrations in the battery chimnez and the calculated emission factor

\begin{tabular}{|l|c|c|c|l|}
\hline \multicolumn{1}{|c|}{ Parameter } & Unit & COB-O & COB-N & \multicolumn{1}{c|}{ Reference data } \\
\hline Concentration & ng I-TEQ/Nm ${ }^{3}$ & 0.0018 & 0.0006 & $\begin{array}{l}0.1 \text { [BREF 2013] } \\
<0.01 \text { [Hein 2009] }\end{array}$ \\
\hline Calculated emission factor* & ng I-TEQ/Mg ${ }_{\text {coke }}$ & 1.70 & 0.53 & $\begin{array}{l}12 \text { [Sobolewski 2010] } \\
1-20 \text { [Hein 2009] }\end{array}$ \\
\hline Calculated annual emission* & mg I-TEQ/year & 1.28 & 0.40 & $\begin{array}{l}100 \text { [Regulation EC 2006] } \\
2636 \text { (for coke production) [Report 2005] }\end{array}$ \\
\hline
\end{tabular}

* Assuming production capacity of $750000 \mathrm{Mg}$ /year. 
[Report 2005, Regulation EC 2006, Hein 2009, Sobolewski 2010, BREF 2013]. The average concentration values of $\mathrm{PCDDs} / \mathrm{PCDF}$ s for COB-O are almost twice higher than reported in [BREF 2013], but for COB-N, they are halved. At the same time, emission factors and annual emissions are far below the maximal values reported in literature. The obtained results can therefore be regarded as a preliminary confirmation of the fact that the underfiring system of $\mathrm{COB}$ produces traces of PCDDs/PCDFs. Even if one assumes annual coke production of one coking plant at the level of $3.5 \mathrm{mln}$ tons, it gives 2-6 mg I-TEQ/year, which is far below $100 \mathrm{mg} \mathrm{I-TEQ/year} \mathrm{included}$ in [Regulation EC 2006].

Assuming that during the coal coking process PCDDs and PCDFs are formed exclusively from mono- and polychlorinated phenols or other precursors, the approximate value of the emission according to [Brzuzy \& Hites 1996] was calculated using the stoichiometry of the reaction. The calculations were based on the chlorine balance during coal pyrolysis in COB (Fig. 5) [Świetlik 2000, Karcz 2002, Koszorek \& Mianowski 1999].

Chlorine is introduced into the coking process with a coal blend. It may occur in both the inorganic and organic form, in which the chlorine ions are associated with carbon by strong covalent bonds or weak physical forces [Świetlik 2000, Karcz 2002, Koszorek \& Mianowski 1999, Strugała 1998]. The next element is the yield of chlorophenols formation. Table 6 shows exemplary substrates, products and yields of such reactions.

Another issue is the yield of PCDDs/PCDFs formation from mono- and polychlorinated phenols. In the calculations, $1.53 \%, 3.39 \%$ and $0.68 \%$ yield from dichlorophenol, trichlorophenol and tetrachlorophenol - respectively - was assumed, according to [Ryu 2008]. Table 7 presents the obtained results, which are based on the balance of chlorine during the coal pyrolysis, as well as reactions of chlorophenols and PCDDs/ PCDFs formation.

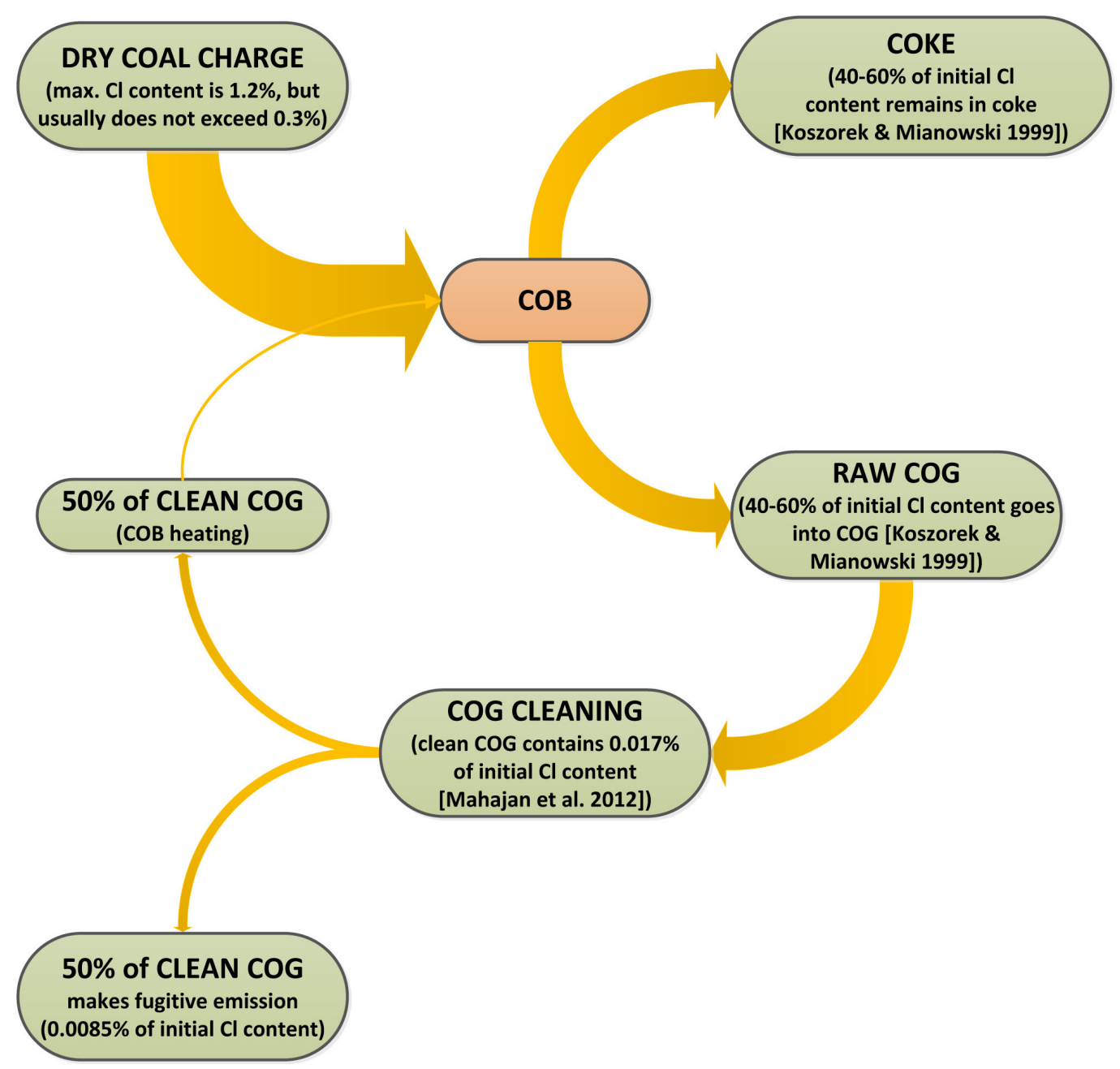

Fig. 5. The balance of chlorine at various stages of the process of coal pyrolysis in COB 
Table 6. Substrates, products and yields of chlorophenols formation reactions

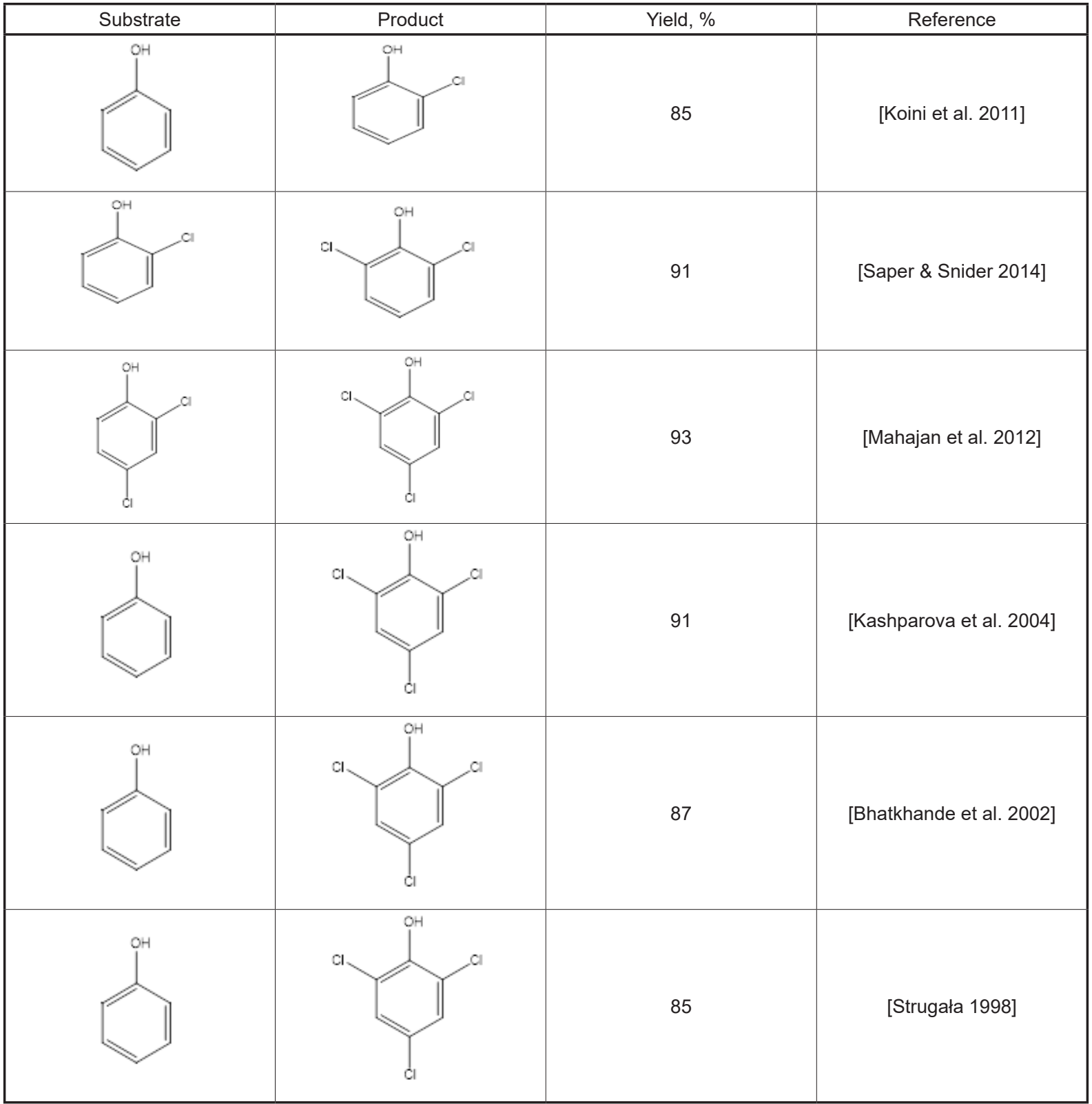

Table 7. Calculated PCDDs/PCDFs emission factor

\begin{tabular}{|l|c|c|c|}
\hline \multicolumn{1}{|c|}{ Substrate } & dichlorophenol & trichlorophenol & tetrachlorophenol \\
\hline Yield of PCDDs/ PCDFs formation, \% & 1.53 & 3.39 & 0.68 \\
\hline $\begin{array}{l}\text { Calculated emission factor assuming coke } \\
\text { procuction capacity of } 750000 \mathrm{Mg} / \mathrm{y}, \mathrm{ng} \text { TEQ/ } / \mathrm{Mg}_{\text {coke }}\end{array}$ & 0.352 & 0.521 & 0.793 \\
\hline
\end{tabular}

\section{RESULTS}

The carried out measurements of PCDDs/ PCDFs concentrations in exhaust gases of $\mathrm{COB}$ underfiring system clearly indicate that the system is not a significant source of emission of these xenobiotics. Our findings suggest that the efficiency of the formation of hazardous xenobiotics under the industrial conditions is slight- ly lower than it has been shown in laboratory methods [Ryu 2008].

As it was proven by the carried out calculations, mono- and polychlorophenols constitute precursors of PCDDs/PCDFs formation. Using the yield of the various stages of the synthesis of these xenobiotics [Ryu 2008, Koini 2011, Saper \& Snider 2014, Mahajan et al. 2012, Kashparova et al. 2004, Bhatkhande et al. 2002, Kajigaeshi 
et al. 1990] and presented chlorine balance at various stages of pyrolysis, the validity of the calculations was confirmed. The measured concentrations of PCDDs/PCDFs are closely related with the calculated values. Therefore, a comprehensive characterization of the PCDDs/PCDFs formation during coal coking should consider the formation mechanisms of these xenobiotics from mono- and polychlorophenols, as well as the influence of process parameters on the synthesis.

\section{REFERENCES}

1. Alcock, R. E., Jones, K.C.: Dioxins in the Environment: Review of Trend Data, Environmental Science\&Technology, 11, 3133-3143, 1996.

2. Bhatkhande B. S., Adhikari M. V., Samant S. D.: Sonochemical chloro-oxidation of phenols using $\mathrm{HCl}-\mathrm{H} 2 \mathrm{O} 2$, Ultrasonics Sonochemistry, nr 9, 31-35, 2002.

3. BREF - Best Available Techniques (BAT) Reference Document for Iron and Steel Production, Industrial Emissions Directive 2010/75/EU (Integrated Pollution Prevention and Control), 2013.

4. Brzuzy, L.P., Hites, R.A.: Global Mass Balance for Polychlorinated Dibenzo-p-dioxins and Dibenzofurans, Environmental Science\&Technology, 6, 1797-1804, 1996.

5. BS EN 1948-1:2006 Stationary source emissions. Determination of the mass concentration of PCDDs/PCDFs and dioxin-like PCBs. Sampling of PCDDs/PCDFs.

6. Fiedler, H.: Formation and Sources of PCDD/PCDF, Organohalogen. Compd., 11, 221-228, 1993

7. Griffin R.D.: A new theory of dioxin formation in municipal solid waste combustion, Chemosphere, 1986, 15 (9-12), 1987-1990.

8. Grochowalski, A. Lasa, J.: PCDDs - hazardous poisons for humans and natural environment (in Polish), Problemy ekologiczne Krakowa nr 13, AGH: Polski Klub Ekologiczny, 5-30, 1989

9. M. Hein, Review of Methods Used for Determination of Emissions to Air From Coke Plants in Germany, Essen, 2009, Non-published.

10. Jones, P.H., Pettit, K., Hillmer, M.J.: Perspective on Dioxin Emissions from Incineration Processes, Filtration \& Separation, 167-173, 1994.

11. Kajigaeshi S., Shinmasu Y., Fujisaki S., Kakinami T.: Halogenation using quaternary ammonium polyhalides. XXVI [1]. Chlorination of phenols with benzyltrimethylammonium tetrachloroiodate, Chemistry Express, no. 5, 141-144, 1990.

12. Karcz A.: Possibilities of alkali and chlorine reduction in blast furnace coke (in Polish), Karbo, nr 10, $287,2002$.
13. Kashparova V. P., Kagan E. Sh., Zhukova I. Yu., Ivakhnenko E. P.: Use of 1-halo derivatives of the 2,2,6,6-tetramethylpiperidine series as oxidants and halogenating agents, Russian Journal of Applied Chemistry, 77, 964-967, 2004.

14. Koini, Eftychia N., Alvonitis N., Calogeropoulou T.: Simple and efficient method for the halogenation of oxygenated aromatic compounds, Synlett, nr 11, 1537-1542, 2011.

15. Kosewska M., Wróbelska K.: Chlorine in coke oven gas at various stages of its purification (in Polish), Karbo, nr 11, 294, 1995.

16. Koszorek A., Mianowski A.: Emission of chlorine compounds during coal coking process (in Polish), Karbo, nr 6, 209, 1999.

17. Mahajan T., Kumar L., Dwivedi, K., Agarwal D.D.: Efficient and Facile Chlorination of Industrially-Important Aromatic Compounds using $\mathrm{NaCl} / \mathrm{p}-\mathrm{TsOH} / \mathrm{NCS}$ in Aqueous Media, Industrial \& Engineering Chemistry Research, 51, 3881 3886, 2012.

18. Regulation (EC) No $166 / 2006$ of the European Parliament and of the Council of 18 January 2006 concerning the establishment of a European Pollutant Release and Transfer Register (E-PRTR) and amending Council Directives 91/689/EEC and 96/61/EC.

19. Report on "Opportunities for Reduction of Dioxin Emissions from the Metallurgical Sector in Poland", Polish-Danish project financed by the Danish Environmental Protection Agency from DANCEE resources, 2005.

20. Ryu J., Formation of chlorinated phenols, dibenzop-dioxins, dibenzofurans, benzenes, benzoquinnones and perchloroethylenes from phenols in oxidative and copper (II) chloride-catalyzed thermal process, ScienceDirect, 1100-1109, 2008.

21. Saper Noam I., Snider Barry B.: 2,2,6,6-Tetramethylpiperidine-Catalyzed, Ortho-selective Chlorination of Phenols by Sulfuryl Chloride, Journal of Organic Chemistry, nr 79, 809-813, 2014

22. Sobolewski A. et al., Methodical guide. Release and transfer of pollutants to the environment from coking plants in Poland (in Polish), IChPW, Zabrze, 2010.

23. Sobolewski A., Best Available Techniques in coking industry (in Polish), Ministerstwo Środowiska, Warszawa, 2005.

24. Strugała A.: Mineral matter in coal and its transformation during coking process (in Polish), Gospodarka surowcami mineralnymi, vol. 14, 1, 1998.

25. Świetlik U.: Chlorine in coal - occurrence and behavior in thermal processes (in Polish), Karbo, nr 11, 358, 2000.

26. Wielgosiński G.: Emission of dioxins from thermal processes and methods of their reduction (in Polish), PAN, Łódź 2009. 